\title{
ASSOCIATION BETWEEN CLASSICAL AND EMERGING RISK FACTORS FOR DIABETIC KIDNEY DISEASE AND ALBUMINURIA IN A COHORT OF TYPE 2 DIABETES MELLITUS PATIENTS
}

\author{
Stoiță Marcel ${ }^{1}$, Popa Amorin Remus ${ }^{1,2}$ \\ ${ }^{1}$ Faculty of Medicine and Pharmacy, University of Oradea, Romania \\ ${ }^{2}$ Clinical County Emergency Hospital of Oradea, Romania \\ Corresponding author: Stoiță Marcel \\ Email: stoitamarcel2020@gmail.com
}

\section{Rezumat}

Prezența albuminuriei la pacienții cu diabet zaharat de tip 2 este un marker al disfuncției endoteliale și, totodată, unul dintre criteriile diagnosticului bolii renale diabetice. Studiul de față a avut ca scop identificarea asocierilor între factorii de risc cardiovascular și excreția renală de albumină la un grup de 218 pacienți cu diabet zaharat de tip 2. Valorile HbAlc, tensiunii arteriale sistolice, tensiunii arteriale diastolice au fost semnificativ statistic mai mari la pacienții cu microalbuinurie sau macroalbuminurie comparativ cu pacienții cu normoalbuminurie $(p<0.01)$. Am identificat o asociere pozitivă semnificativă statistic între valorile acidului uric și albuminurie, respectiv deficiența de 25-(OH)2 vitamina D3 și microalbuminurie $(p<0,01)$.

Cuvinte cheie: diabet zaharat, microalbuminurie, hiperuricemie, vitamina $D$.

\begin{abstract}
The presence of albuminuria in patients with type 2 diabetes mellitus is a marker of endothelial dysfunction and also one of the criteria for diagnosing diabetic kidney disease. The present study aimed to identify associations between cardiovascular risk factors and renal albumin excretion in a group of 218 patients with type 2 diabetes mellitus. HbAlc values, systolic blood pressure, diastolic blood pressure were statistically significantly higher in patients with microalbuinuria or macroalbuminuria compared to patients with normoalbuminuria $(p<0.01)$. We identified a statistically significant positive association between uric acid values and albuminuria, respectively 25- $(\mathrm{OH}) 2$ vitamin D3 deficiency and microalbuminuria $(p<0.01)$.
\end{abstract}

Keywords: diabetes, microalbuminuria, hyperuricemia, vitamin D. 


\section{INTERNAL}

\section{Original Papers}

\section{Introduction}

Patients with diabetes mellitus are about 2 times more likely to suffer from chronic kidney disease than people who do not have diabetes $^{(1)}$. In the NHANES study in patients evaluated from 2009 to 2014, the prevalence of chronic kidney disease in patients with diabetes mellitus was $26.2 \%$, the diagnostic criteria being the presence of albuminuria ${ }^{(2)}$. In diabetes mellitus patients over 65 years of age, the prevalence of reduced glomerular filtration rate was higher than in young patients, while albuminuria had comparable prevalence in both categories. The prevalence of chronic kidney disease in patients with diabetes mellitus in 2008 in Shanghai, China was $33.5 \%{ }^{(3)}$.

In Singapore the prevalence of chronic kidney disease in patients with diabetes was $53 \%$, in $21 \%$ of patients a glomerular filtration rate $<60 \mathrm{~mL} / \mathrm{min} / 1.73 \mathrm{~m}^{2}$ was identified, $48 \%$ had albuminuria $\geq 30 \mathrm{mg} / \mathrm{g}$, and $28 \%$ they had diabetic retinopathy ${ }^{(4)}$.

In literature the factors that were associated with diabetic kidney disease were the presence of diabetic neuropathy, hypertension, hypertriglyceridemia, increased $\mathrm{BMI}$, increased duration of diabetes, $\mathrm{HbAlC} \geq 8 \%$ and the presence of cardiovascular disease.

Hyperuricemia is being more frequently recognized as a risk factor for diabetic kidney disease ${ }^{(5)}$. Numerous studies indicate that hyperuricemia is independently associated with chronic kidney disease ${ }^{(6,7,8,9)}$.

According to a cross-sectional study that included 2,108 Chinese patients with type 2 diabetes, there was a positive correlation between uric acid values and albuminuria and impaired renal function ${ }^{(10)}$. Another study demonstrated that during a 5-year follow-up of 1,449 type 2 diabetic patients with normal renal function, the presence of hyperuricemia was identified as an independent risk factor for the development of diabetic kidney disease ${ }^{(11)}$.

Although the pathogenesis of diabetic kidney disease has not been fully investigated, it is currently thought to be related to glucose and lipid metabolism disorders, renal hemodynamic abnormalities, oxidative stress, elevated vasoactive substances, cytokines and genetic factors. Numerous studies have identified a clear correlation between vitamin D deficiency and type 2 diabetes, and vitamin $D$ deficiency is quite common in patients with chronic renal failure ${ }^{(12)}$. Therefore, numerous risk factors for diabetic kidney disease are being recognized contributing to a more profound understanding of this disease.

The present study aims to evaluate the correlation between albuminuria in patients with type 2 diabetes and uric acid and the correlation between albuminuria and vitamin D. 


\begin{tabular}{|c|c|c|c|c|}
\hline Parameter & $\begin{array}{l}\text { Normoalbuminuri } \\
\text { a }(n=94)\end{array}$ & $\begin{array}{l}\text { Microalbuminur } \\
\text { ia }(n=104)\end{array}$ & $\begin{array}{l}\text { Macroalbuminuria } \\
(n=20)\end{array}$ & $p$ \\
\hline Age & $48.12 \pm 8.71$ & $50.78 \pm 8.56$ & $50.25 \pm 8.36$ & 0.03 \\
\hline $\operatorname{sex}(\% \operatorname{men})$ & $67.74 \%$ & $50.96 \%$ & $65.00 \%$ & 0.01 \\
\hline Creatinine $(\mathrm{mg} / \mathrm{dL})$ & $0.74 \pm 0.16$ & $0.68 \pm 0.16$ & $0.80 \pm 0.22$ & 0.098 \\
\hline Urea (mg/dL) & $18.38 \pm 4.38$ & $17.53 \pm 4.08$ & $19.43 \pm 5.19$ & 0.15 \\
\hline $\mathrm{HbA1c}(\%)$ & $7.80 \pm 1.38$ & $8.35 \pm 1.49$ & $8.32 \pm 1.28$ & 0.0088 \\
\hline $\begin{array}{l}\text { Albumin/creatinine } \\
\text { ratio }(\mathrm{mg} / \mathrm{g})\end{array}$ & $\begin{array}{l}19.99 \pm \\
(15.75,24.85)\end{array}$ & $\begin{array}{l}80.71 \\
(39.93,90.84)\end{array}$ & $\begin{array}{l}569.43 \\
(354.57,640.78)\end{array}$ & 0.0001 \\
\hline BMI $\left(\mathrm{kg} / \mathrm{m}^{2}\right)$ & $26.78 \pm 3.91$ & $27.34 \pm 3.89$ & $28.95 \pm 4.19$ & 0.31 \\
\hline Hypertension (\%) & 45.16 & 59.61 & 90.00 & 0.0001 \\
\hline $\mathrm{SBP}(\mathrm{mmHg})$ & $128.55 \pm 14.03$ & $135.25 \pm 16.49$ & $141.35 \pm 15.56$ & 0.0026 \\
\hline $\mathrm{DBP}(\mathrm{mmHg})$ & $79.23 \pm 9.25$ & $83 \pm 10.51$ & $87.05 \pm 9.01$ & 0.0087 \\
\hline $\begin{array}{l}\text { GFR } \\
\left(\mathrm{mL} / \mathrm{min} / 1.73 \mathrm{~m}^{2}{ }^{2}\right)\end{array}$ & $105.11 \pm 11.48$ & $105.83 \pm 10.63$ & $99.01 \pm 16.88$ & 0.67 \\
\hline $\begin{array}{l}\text { 1,25 -(OH)2 Vitamin } \\
\text { D 3(nmol/L) }\end{array}$ & $45.40 \pm 16.16$ & $40.54 \pm 13.84$ & $38.92 \pm 18.13$ & 0.045 \\
\hline Uric acid (mg/dL) & $5.49 \pm 1.22$ & $5.55 \pm 1.54$ & $6.27 \pm 1.53$ & 0.76 \\
\hline Diabetes duration & $6.12 \pm 4.94$ & $6.38 \pm 5.79$ & $8.03 \pm 6.17$ & 0.74 \\
\hline Colesterol (mg/dL) & $180.85 \pm 40.73$ & $186.89 \pm 41.21$ & $173.24 \pm 41.76$ & 0.68 \\
\hline $\begin{array}{l}\text { LDL-cholesterol } \\
\text { (mg/dL) }\end{array}$ & $123.40 \pm 31.63$ & $121.59 \pm 37.18$ & $103.8 \pm 26.33$ & 0.77 \\
\hline Tryglicerides (mg/dL) & $\begin{array}{l}175.20 \pm \\
(94.76,183.33)\end{array}$ & $\begin{array}{l}201.64 \\
(99.19,232.27)\end{array}$ & $\begin{array}{l}275.98 \\
(123.99,266.81)\end{array}$ & 0.26 \\
\hline $\begin{array}{l}\text { HDL-cholesterol } \\
(\mathrm{mg} / \mathrm{dL})\end{array}$ & $42.59 \pm 11.05$ & $43.18 \pm 12.44$ & $39.38 \pm 12.51$ & 0.72 \\
\hline
\end{tabular}

Table 1. Clinical-biochemical characteristics according to the level of albuminuria 


\section{INTERNAL}

\section{Original Papers}

\section{Material and method}

The present study included patients with type 2 diabetes who were evaluated at the County Clinical Hospital in Oradea, Bihor. The inclusion criteria applied for this investigation were: age between 18 and 75 years, type 2 diabetes confirmed by $\mathrm{HbAlc}$ determination, individuals who agreed to be investigated. The exclusion criteria were: patients with glomerular filtration rate $<15 \mathrm{~mL} / \mathrm{min} / 1.73 \mathrm{~m}^{2}$ or those on dialysis, patients with liver cirrhosis, patients with neoplastic diseases, patients with mental illness, patients with hypertension grade III defined as SBP $\geq 180$ $\mathrm{mmHg}$ or $D B P \geq 120 \mathrm{mmHg}$, patients suffering from glomerular or tubular diseases, patients with $\mathrm{HbAlc}>12 \%$, patients with acute or chronic urinary tract infections. The study was done between September 1, 2019 and March 31, 2020. A number of 299 were initially considered eligible for inclusion in the study but after applying the inclusion and exclusion criteria only 218 of them remained in the study. The research was conducted with the approval of the Ethics Commission of Oradea County Hospital. The glomerular filtration rate was calculated using the CKD-EPI equation. In addition to the usual laboratory determinations like $\mathrm{HbAlc}$, lipid profile, creatinine, urea, it was done the determination of the albumin/creatinine ratio in the urine spot, the serum value of uric acid and the serum value of $1,25-(\mathrm{OH}) 2$-vitamin D3. Turbidimetry was used for determination of albumin/creatinine ratio, determination of 1,25-(OH)2-vitamin D3 was performed by chemiluminescence and uric acid by colorimetric enzymatic method. All the examinations mentioned above were performed in the hospital laboratory. The presence of microalbuminuria or macroalbuminuria was considered a diagnostic criterion for impaired renal function, we did not use the diagnosis of chronic kidney disease because we could not document the presence of a persistent elevated albuminuria. Microalbuminuria was defined as estimated albumin/creatinine ratio on between $30-300 \mathrm{mg} / \mathrm{g}$ and macroalbuminuria as albumin/creatinine ratio $\geq 300 \mathrm{mg} / \mathrm{g}$. Values of $1,25-(\mathrm{OH}) 2$ vitamin D3 $>50 \mathrm{nmol} / \mathrm{L}$ were considered normal and vitamin $\mathrm{D}$ deficiency was defined as 1,25-(OH)2-vitamin D3 $\leq 50 \mathrm{nmol} / \mathrm{L}$. Hyperuricemia was defined as the serum value of uric acid $\geq 7 \mathrm{mg} / \mathrm{dL}$. Good control of glycaemic values was defined as $\mathrm{HbAlc}<7 \%$. A binary variable was defined, the deficiency of 25-(OH)2-vitamin D3, with a value of 1 if $1,25-(\mathrm{OH}) 2$-vitamin $\mathrm{D} 3 \leq 50 \mathrm{nmol} / \mathrm{L}$ and 0 if 1,25-(OH)2-vitamin D3 >50 nmol/L.

Statistical processing was performed using Biostat software. The average values of the different parameters were compared using 


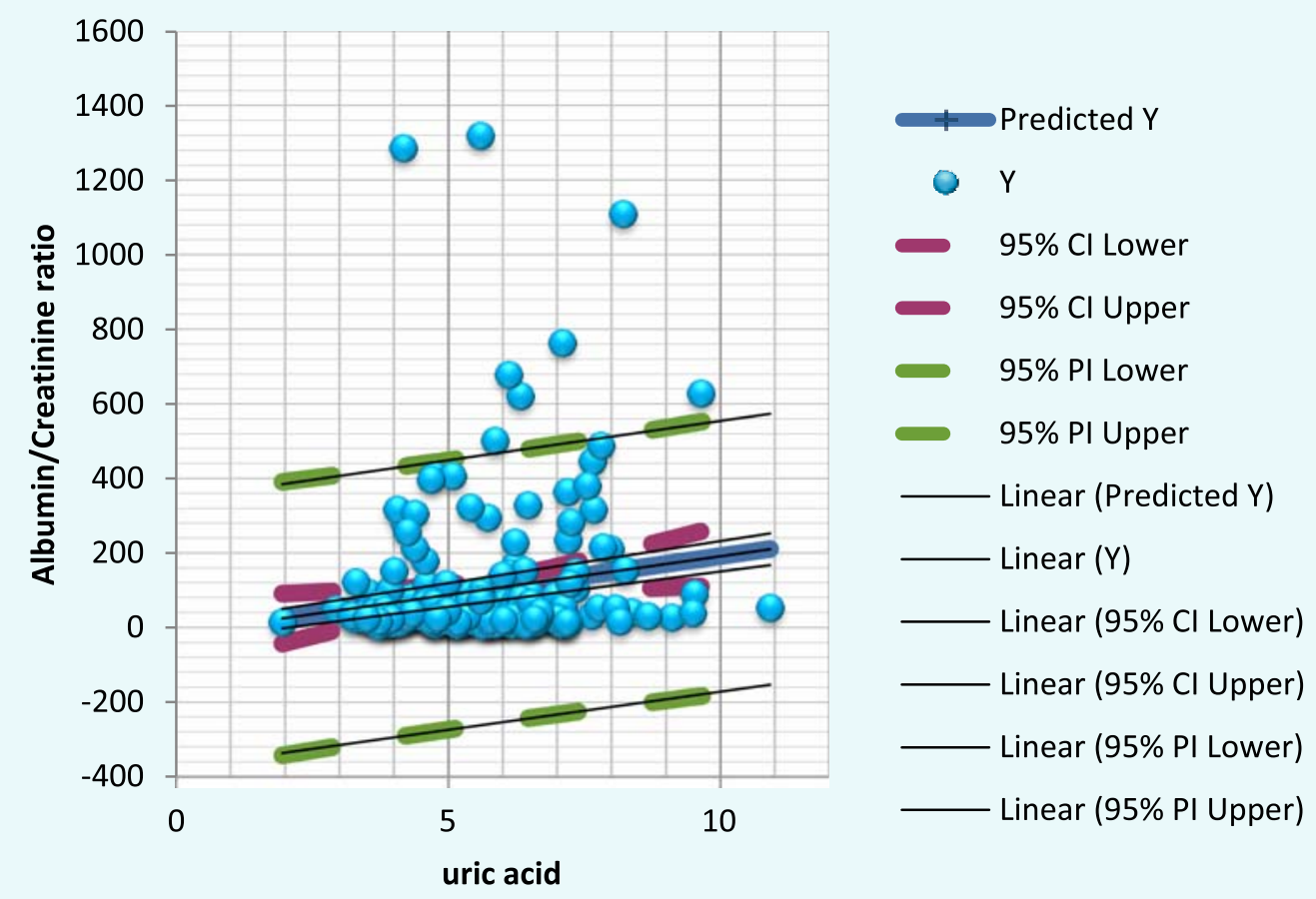

Figure1. Correlation between serum uric acid value and albumin/creatinine ratio

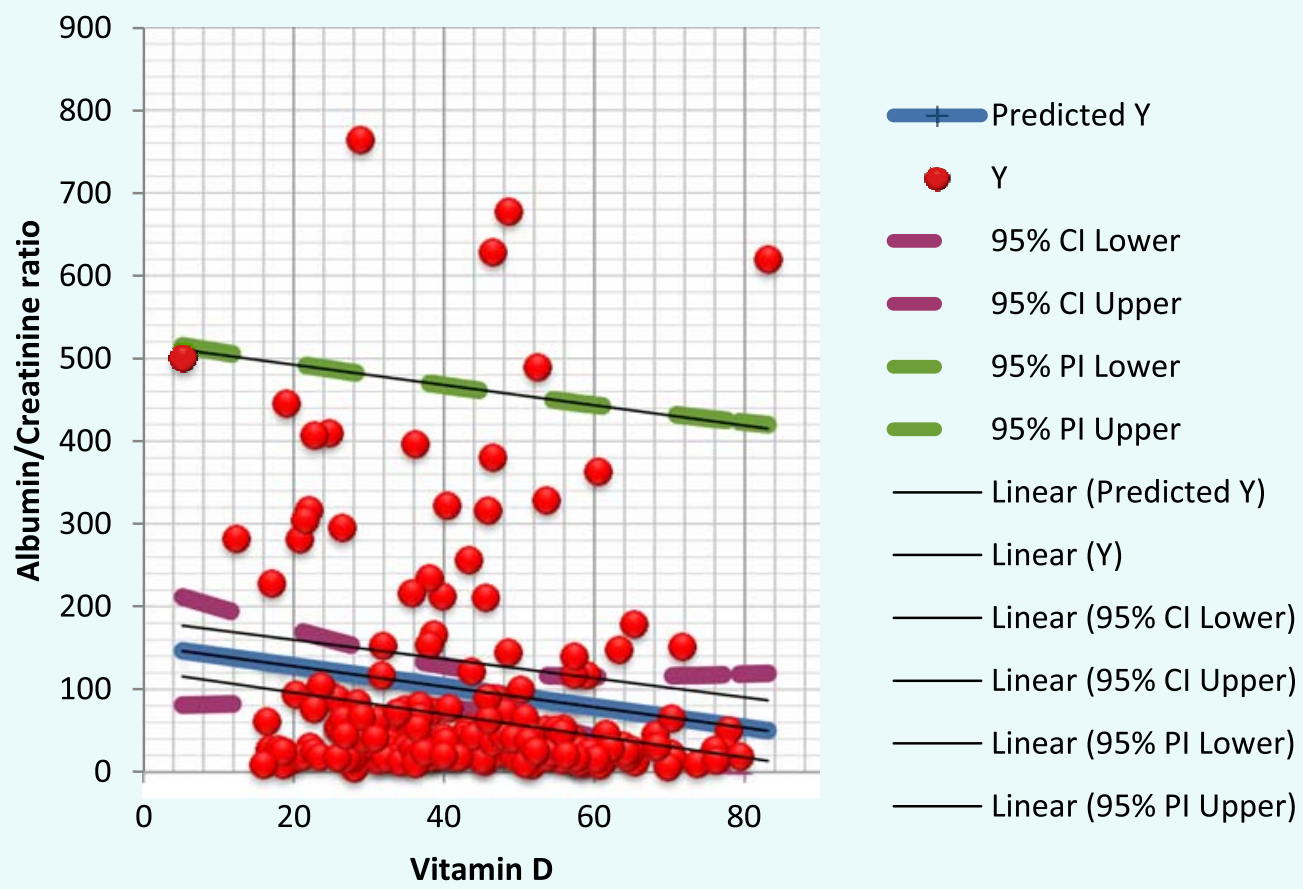

Figure 2. Correlation between serum 1,25-(OH)2-vitamin D3 value and albumin/creatinine ratio 


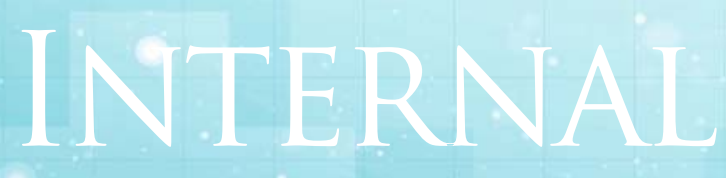

Original Papers

the Anova test. A value of $p<0.05$ was considered statistically significant. Univariate regression and multivariate regression were used to assess correlation between variables.

\section{Results and discussion}

\section{Correlation between uric acid values and albumin/creatinine ratio}

In figure 1 it is shown that there is a statistically significant correlation between the value of serum uric acid and the urinary albumin/creatinine ratio. High uric acid levels are associated with elevated urinary albumin/creatinine ratio $(p=0,01)$.

\section{Correlation between 1,25-(OH)2-vitamin D3 values and albumin/ creatinine ratio}

In figure 2 it is shown that there is no statistically significant correlation between serum 1,25-(OH)2-vitamin D3 and urinary albumin / creatinine ratio ( $p=0.13$ ).

\section{Correlation between 25-(OH)2-vitamin D3} status and albumin/creatine ratio after adjustment based on multiple factors

A positive association has been found has been found between 25-(OH)2-vitamin D3 deficiency and albumin/creatine ratio.

Our results are in concordance with the results from literature demonstrating that hyperuricemia and vitamin $D$ deficiency play a role in the pathogenesis of diabetic kidney disease. It has been demonstrated that uric acid increases oxidative stress and promotes the activation of the renin-angiotensinaldosterone system ${ }^{(13,14)}$. Uric acid is associated with early diabetic kidney disease ${ }^{(15,16)}$, and can be a factor that can predict the progression of microalbuminuria ${ }^{(17)}$.

Observational studies have demonstrated that serum uric acid and microalbuminuria levels were significantly positively correlated with kidney disease in patients with type 2 diabetes ${ }^{(18)}$. Patients with higher uric acid levels have worse renal function, regardless of glycated haemoglobin (HbAlc) or the duration of diabetes mellitus ${ }^{(19)}$. Xanthine oxidase $(\mathrm{XO})$ is a very important enzyme that has the role for converting sulfhydryl groups to uric acid. Data from literature has demonstrated that an increase in uric acid by $1 \mu \mathrm{mol} / \mathrm{L}$ increased the risk of albuminuria by $1.5 \%$, and an increase in XO activity by $1 \mathrm{U} / \mathrm{L}$ increased the risk of albuminuria by $1.5 \%$. In diabetes mellitus patients, both $\mathrm{XO}$ and uric acid are independently associated with albuminuria ${ }^{(20)}$.

Numerous data support the association between low 1,25-(OH)2-vitamin D3 serum values and worse renal function. In a study done on 1,216 patients with diabetes was identified an independent association between vitamin $D$ deficiency and the onset of diabetic kidney disease ${ }^{(21)}$. Levin and 


\begin{tabular}{|l|l|l|l|l|l|l|}
\hline & Coefficient & $\begin{array}{l}\text { Standard } \\
\text { error }\end{array}$ & $\begin{array}{l}\text { Lower } \\
\text { confidence } \\
\text { interval }\end{array}$ & $\begin{array}{l}\text { Upper } \\
\text { confidence } \\
\text { interval }\end{array}$ & t Sta tic & $p$-value \\
\hline Uric acid & 20.7728 & $\mathbf{8 . 7 1 3 6}$ & 3.5978 & 37.9478 & 2.3840 & 0.0180 \\
\hline $\begin{array}{l}1,25- \\
(\mathrm{OH}) 2- \\
\text { vitamin } \\
\text { D3 value }\end{array}$ & -1.2347 & 0.8146 & -2.8403 & 0.3710 & -1.5156 & 0.1311 \\
\hline
\end{tabular}

Table 2. Linear regression parameters between serum uric acid value and albumin/creatinine ratio and linear regression parameters between 1,25-(OH)2-vitamin D3 value and albumin /creatinine ratio

\begin{tabular}{|l|l|l|l|l|l|l|}
\hline & Coefficient & $\begin{array}{l}\text { Standard } \\
\text { error }\end{array}$ & $\begin{array}{l}\text { Lower } \\
\text { confidence } \\
\text { interval }\end{array}$ & $\begin{array}{l}\text { Upper } \\
\text { confidence } \\
\text { interval }\end{array}$ & t Static & p-value \\
\hline Intercept & -1.1631 & 0.4732 & -2.0960 & -0.2302 & -2.4582 & 0.0148 \\
\hline Age & 0.0057 & 0.0048 & -0.0038 & 0.0152 & 1.1790 & 0.2398 \\
\hline Sex & -0.0583 & 0.0817 & -0.2195 & 0.1028 & -0.7133 & 0.4765 \\
\hline HbA1c & 0.0630 & 0.0232 & 0.0173 & 0.1087 & 2.7168 & 0.0072 \\
\hline BMI & 0.0030 & 0.0093 & -0.0153 & 0.0213 & 0.3253 & 0.7453 \\
\hline SBP & 0.0050 & 0.0023 & 0.0005 & 0.0095 & 2.1745 & 0.0308 \\
\hline Uric acid & 0.0407 & 0.0265 & -0.0116 & 0.0930 & 1.5339 & 0.1266 \\
\hline $\begin{array}{l}\text { Diabetes } \\
\text { duration }\end{array}$ & -0.0015 & 0.0068 & -0.0148 & 0.0119 & -0.2146 & 0.8303 \\
\hline Cholesterol & -0.0008 & 0.0046 & -0.0100 & 0.0083 & -0.1758 & 0.8606 \\
\hline LDL-cholesterol & -0.0005 & 0.0047 & -0.0097 & 0.0087 & -0.1138 & 0.9095 \\
\hline Tryglicerides & 0.0001 & 0.0006 & -0.0010 & 0.0013 & 0.2415 & 0.8094 \\
\hline HDL-cholesterol & 0.0022 & 0.0052 & -0.0081 & 0.0124 & 0.4158 & 0.6780 \\
\hline $\begin{array}{l}1,25 \text {-(OH)2 - } \\
\text { vitamin D3 } \\
\text { deficiency }\end{array}$ & 0.1649 & 0.0739 & 0.0193 & 0.3106 & 2.2325 & 0.0267 \\
\hline
\end{tabular}

Table 3. Correlation between 25-(OH)2-vitamin D3 status and albumin/creatine ratio after adjustment for multiple factors by multiple linear regression 


\section{INTERNAL}

\section{Original Papers}

colleagues demonstrated that in diabetes mellitus patients low serum levels of 1,25$(\mathrm{OH})$-vitamin D3 were independently associated with lower glomerular filtration rate and with a high urinary albumincreatinine ratio ${ }^{(22)}$. Also, supplementation with vitamin $D$ can be helpful in reducing the mortality of diabetes mellitus patients with very advanced kidney disease, in a study done on haemodialysis patients it was found that patients who received vitamin $D$ supplements had a significantly higher 2-year survival rate than patients who did not receive ${ }^{(23)}$, suggesting efficacy. vitamin $D$ in reducing mortality in patients with end-stage renal disease. Furthermore, animal studies have shown that serum levels of $25(\mathrm{OH})$ vitamin $D$ and $1.25(\mathrm{OH}) 2$ vitamin D3 were significantly reduced in rats with diabetic kidney disease and treatment with rat vitamin D effectively inhibited proliferation of mesangial cells induced by hyperglycaemia ${ }^{(24)}$. In another animal study, diabetic mice with vitamin D -/receptor mutations had more severe renal impairment and were more likely to have severe proteinuria and glomerulosclerosis compared with wild-type mice ${ }^{(25)}$.

\section{Conclusion}

In our study we demonstrated a statistically significant correlation between uric acid levels and albumin/creatinine ratio in univariate regression and between 25-(OH)2vitamin D3 deficiency and albumin/creatinine ration in multivariate regression. The role of hyperuricemia and 1,25-(OH)2 vitamin D3 need to be further explored for a better understanding of the pathogenesis of diabetic kidney disease.

Funding: none.

Conflict of interest statement: none declared.

\section{References}

1. Koye DN, Magliano DJ, Nelson RG, Pavkov ME. The Global Epidemiology of Diabetes and Kidney Disease. Adv Chronic Kidney Dis. 2018 Mar;25(2):121-132. doi: 10.1053/j.ackd.2017.10.011. Review. PubMed PMID: 29580576.,

2. Afkarian M, Zelnick $L R$, Hall $Y N$, et al. Clinical Manifestations of Kidney Disease Among US Adults With Diabetes, 1988-2014. JAMA. 2016;316(6):602-610. doi:10.1001/jama.2016.10924

3. Zhou Y, Echouffo-TcheuguiJB, GuJJ, et al. Prevalence of chronic kidney disease across levels of glycemia among adults in Pudong New Area, Shanghai, China. BMC Nephrol. 2013;14:253. Published 2013 Nov 16. doi:10.1186/1471-2369-14-253

4. Brück K, Stel VS, Gambaro G, et al. CKD Prevalence Varies across the European General Population. J Am Soc Nephrol. 2016;27(7):2135-2147. doi:10.1681/ ASN.2015050542

5. Johnson RJ, Nakagawa T, Jalal D, Sanchez-Lozada LG, Kang DH, Ritz E. Uric acid and chronic kidney disease: which is chasing which? Nephrol Dial Transplant. 2013;28(9):2221-8. Epub 2013/04/02. pmid:23543594.

6. Miyaoka T, Mochizuki T, Takei T, Tsuchiya K, Nitta K. Serum uric acid levels and long-term outcomes in chronic kidney disease. Heart Vessels. 2014;29(4):504-12.

7. Zoppini G, Targher G, Chonchol M, Ortalda V, Abaterusso C, Pichiri l, et al. Serum uric acid levels and 
incident chronic kidney disease in patients with type 2 diabetes and preserved kidney function. Diabetes Care. 2012;35(1):99-104.

8. Jalal DI, Maahs DM, Hovind P, Nakagawa T. Uric acid as a mediator of diabetic nephropathy. Semin Nephrol. 2011;31(5):459-65. pmid:22000654; PubMed Central PMCID: PMC3197214.

9. Ito H, Abe M, Mifune M, Oshikiri K, Antoku S, Takeuchi $Y$, et al. Hyperuricemia is independently associated with coronary heart disease and renal dysfunction in patients with type 2 diabetes mellitus. PLoS One. 2011;6(11):e27817. pmid:22125626; PubMed Central PMCID: PMC3220675.

10. Cai $X L$, Han $X Y$, Ji LN. High-normal serum uric acid is associated with albuminuria and impaired glomerular filtration rate in Chinese type 2 diabetic patients. Chin Med J (Engl). 2011;124(22):3629-34. Epub 2012/02/22. pmid:22340215.

11. Zoppini G, Targher G, Chonchol M, Ortalda V, Abaterusso $C$, Pichiri l, et al. Serum uric acid levels and incident chronic kidney disease in patients with type 2 diabetes and preserved kidney function. Diabetes Care. 2012;35(1):99-104. Epub 2011/10/27. pmid:22028277; PubMed Central PMCID: PMCPmc3241303.

12. Zhang $Z$, Sun $L$, Wang $Y$, et al. Renoprotective role of the vitamin $D$ receptor in diabetic nephropathy. Kidney Int. 2008. 73(2): 163-71

13. Lytvyn Y., Perkins B. A., Cherney D. Z. I. Uric acid as a biomarker and a therapeutic target in diabetes. Canadian Journal of Diabetes. 2015;39(3):239-246. doi: 10.1016/j.jcjd.2014.10.013

14. Chang Y.-H., Lei C.-C., Lin K.-C., Chang D.-M., Hsieh C.-H., Lee Y.-J. Serum uric acid level as an indicator for CKD regression and progression in patients with type 2 diabetes mellitus-a 4.6-year cohort study. Diabetes/ Metabolism Research and Reviews. 2016;32(6): 557-564. doi: 10.1002/dmrr.2768

15. De Cosmo S., Viazzi F., Pacilli A., et al. Serum uric acid and risk of CKD in type 2 diabetes. Clinical Journal of the American Society of Nephrology. 2015;10(11): 1921-1929. doi: 10.2215/cjn.03140315.

16. Li G. X., Jiao X. H., Cheng X. B. Correlations between blood uric acid and the incidence and progression of type 2 diabetes nephropathy. European Review for Medical and Pharmacological Sciences. 2018;22(2):506-511

17. Hayashino Y., Okamura S., Tsujii S., Ishii H. Association of serum uric acid levels with the risk of development or progression of albuminuria among Japanese patients with type 2 diabetes: a prospective cohort study [Diabetes Distress and Care Registry at Tenri (DDCRT 10)] Acta Diabetologica. 2016;53(4): 599-607. doi: 10.1007/s00592-015-0825-x

18. Latif H., lqbal A., Rathore R., et al. Correlation between serum uric acid level and microalbuminuria in type-2 diabetic nephropathy. Pakistan Journal of Medical Sciences. 2017;33(6):1371-1375. doi: 10.12669/ pjms.336.13224

19. Pizarro M. H., Santos D. C., Barros B. S. V., et al. Serum uric acid and renal function in patients with type 1 diabetes: a nationwide study in Brazil. Diabetology and Metabolic Syndrome. 2018;10 doi: 10.1186/s13098-0180324-7.

20. Klisic A., Kocic G., Kavaric N., Jovanovic M., Stanisic V., Ninic A. Xanthine oxidase and uric acid as independent predictors of albuminuria in patients with diabetes mellitus type 2. Clinical and Experimental Medicine. 2018;18(2):283-290. doi: 10.1007/s10238017-0483-0

21. Diaz VA, Mainous AG 3rd, Carek PJ, Wessell AM, Everett $C$. The association of vitamin $D$ deficiency and insufficiency with diabetic nephropathy: implications for health disparities. J Am Board Fam Med. 2009. 22(5): 521 7.

22. Levin A, Bakris GL, Molitch $M$, et al. Prevalence of abnormal serum vitamin D, PTH, calcium, and phosphorus in patients with chronic kidney disease: results of the study to evaluate early kidney disease. Kidney Int. 2007. 71(1): 31-8.

23. Teng $M$, Wolf $M$, Ofsthun $M N$, et al. Activated injectable vitamin $D$ and hemodialysis survival:a historical cohort study. J Am Soc Nephrol. 2005. 16(4): 1115-25

24. Wang Y, Zhu J, DeLuca HF. The vitamin D receptor in the proximal renal tubule is a key regulator of serum 1a,25-dihydroxyvitamin $D_{3}$. Am J Physiol Endocrinol Metab. 2015.308(3): E201-5

25. Zhang Z, Sun L, Wang $Y$, et al. Renoprotective role of the vitamin $D$ receptor in diabetic nephropathy. Kidney Int. 2008. 73(2): 163-71. 